\title{
Bible Department Gender Issues: A Study of Ohio Christian High School Bible Departments
}

Elizabeth A. Hacker

Cedarville University

Follow this and additional works at: https://digitalcommons.cedarville.edu/education_theses

Part of the Biblical Studies Commons, and the Education Commons

\section{Recommended Citation}

Hacker, Elizabeth A., "Bible Department Gender Issues: A Study of Ohio Christian High School Bible Departments" (2012). Master of Education Research Theses. 42.

https://digitalcommons.cedarville.edu/education_theses/42 


\title{
Running head: BIBLE DEPARMENT GENDER ISSUES \\ BIBLE DEPARTMENT GENDER ISSUES: \\ A STUDY OF OHIO CHRISTIAN HIGH SCHOOL BIBLE DEPARTMENTS
}

A thesis submitted in partial fulfillment of the requirements for the degree of Masters of Education

\section{By}

\author{
ELIZABETH ANNE HACKER
}

B.A. Integrated Social Studies Education, Cedarville University, 2004

B.A. History, Cedarville University, 2004

2012

Cedarville University 
BIBLE DEPARTMENT GENDER ISSUES

CEDARVILLE UNIVERSITY

SCHOOL OF GRADUATE STUDIES

March 19, 2012

I HEREBY RECOMMEND THAT THE THESIS PREPARED UNDER MY SUPERVISION BY Elizabeth Anne Hacker ENTITLED Bible Department Gender Issues: A Study of Ohio Christian School Bible Departments BE ACCEPTED IN PARTIAL FULFILLMENT OF THE REQUIREMENTS FOR THE DEGREE OF Master of Education.

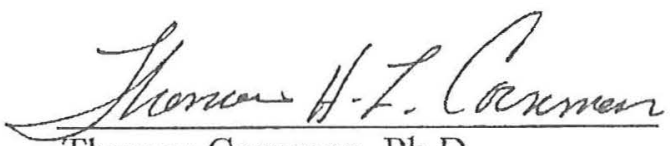

Thomas Cornman, Ph.D.

Academic Vice President
Stephen S. Gruber, Ed.D.

Education Department Chair

Director M.Ed. Program

Thesis/Project Advisor

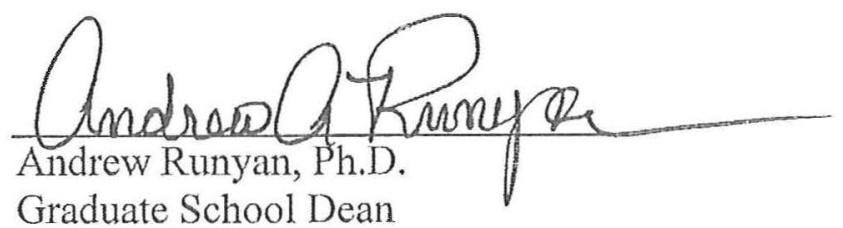




\begin{abstract}
Hacker, Elizabeth A. M.Ed., Education Department, Cedarville University, 2012. Bible Department Gender Issues: A Study of Ohio Christian School Bible Departments.
\end{abstract}

This mixed method study examines the Bible department staff make-up of Ohio Christian high schools and examines administrators, parents, and students' views about females teaching Bible. Surveys were sent to 37 administrators to examine the current faculty make-up of their Bible departments and to evaluate administrators, parents, and students' perceptions of female Bible teachers. Fourteen female students wrote their perceptions of an all girls Bible class in their journals. Analysis of the surveys and journals found that while few females teach in Bible departments, administrators are not necessarily opposed to females teaching. Parents prefer an all girls Bible class taught by a female for their daughter. Female students feel more comfortable discussing personal issues in an all girls Bible class. These results can be used to inform Christian school educators and stakeholders about the various perceptions of gender issues in Bible departments, specifically the perceptions of females teaching the Bible. 
BIBLE DEPARTMENT GENDER ISSUES

\section{TABLE OF CONTENTS}

Page

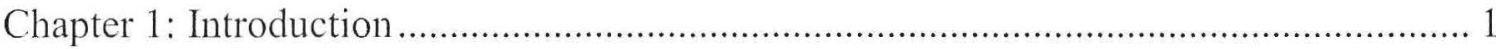

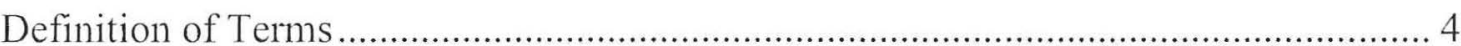

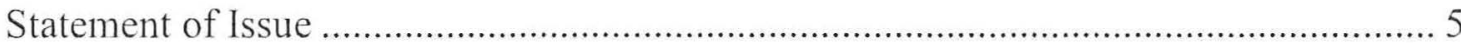

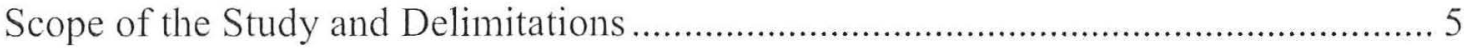

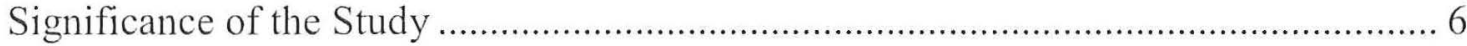

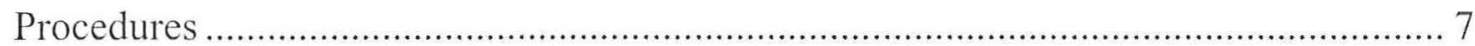

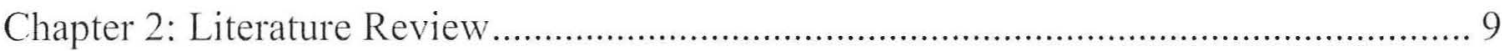

History of Religious Education and Private Christian Schools in America .................. 9

Characteristics of Christian Schools ........................................................................ 10

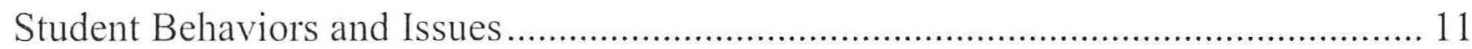

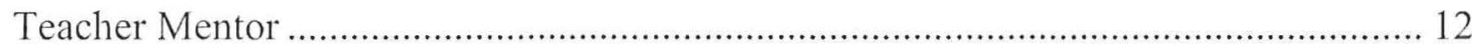

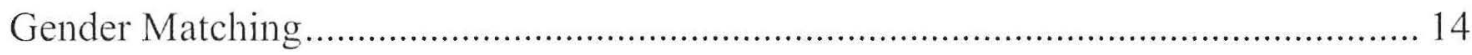

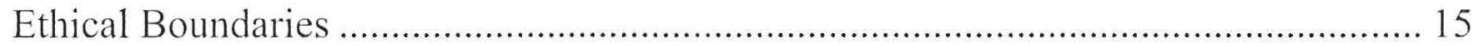

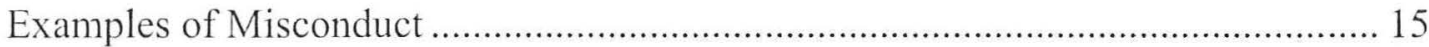

Teachers and Students Rate Teachers ……......................................................... 16

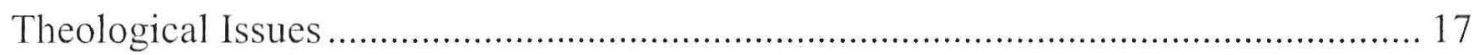

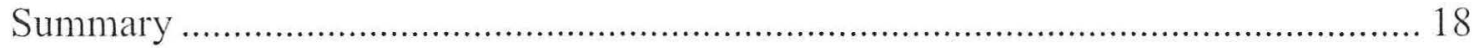

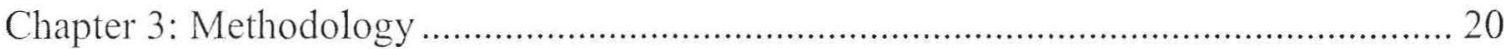




\section{BIBLE DEPARTMENT GENDER ISSUES}

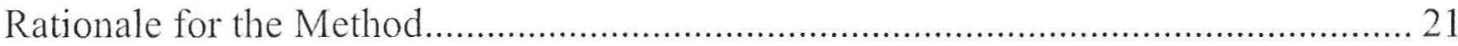

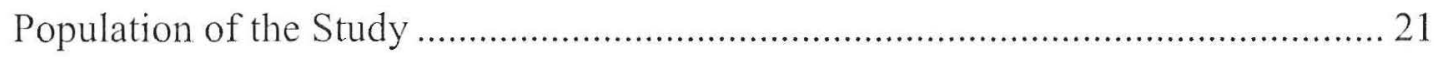

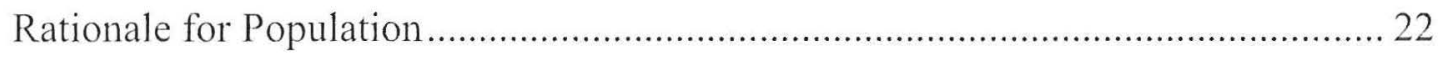

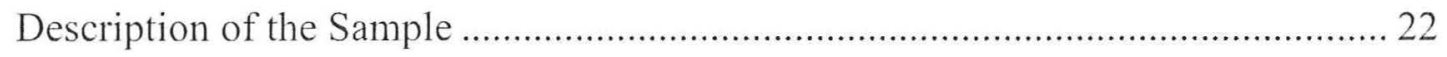

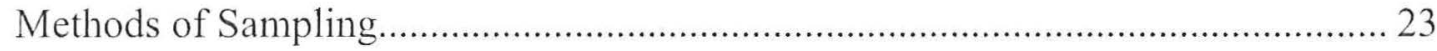

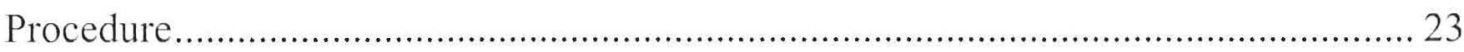

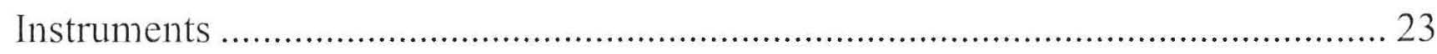

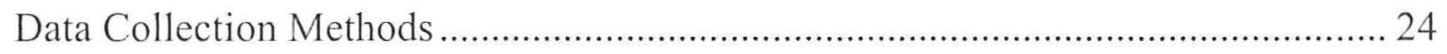

Relevant Ethical Considerations................................................................... 24

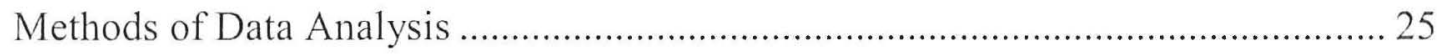

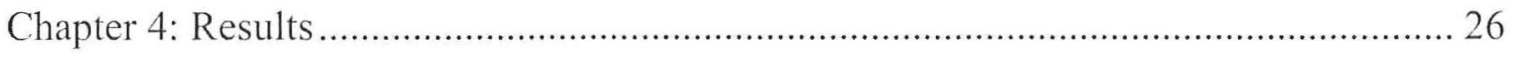

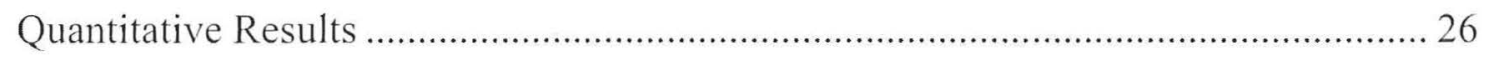

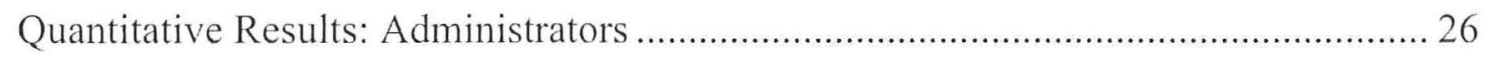

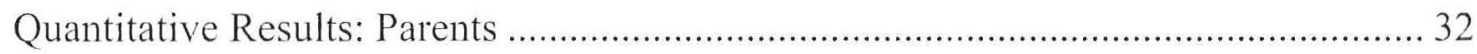

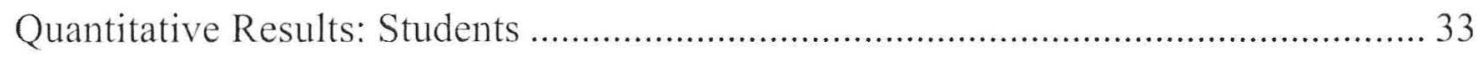

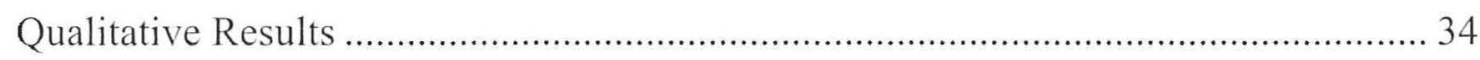

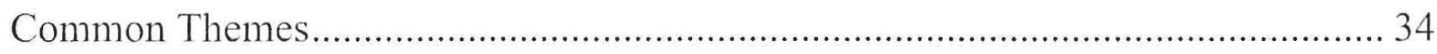

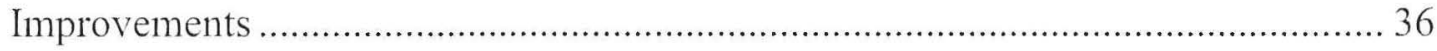

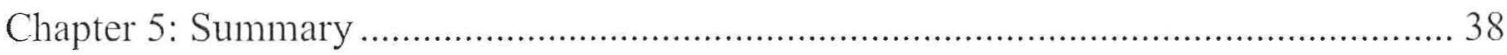

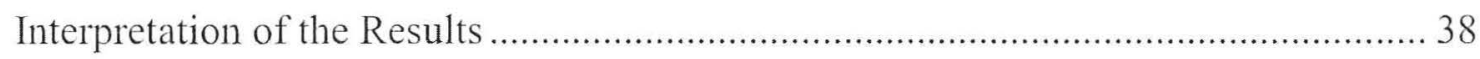


BIBLE DEPARTMENT GENDER ISSUES

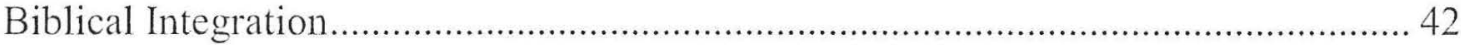

Relation of the Results to Literature ......................................................................... 43

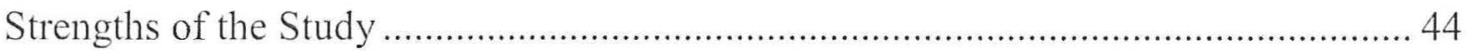

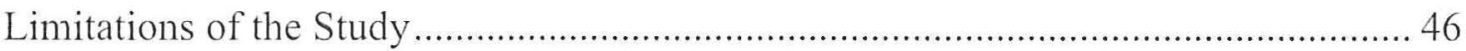

Remaining Threats to Internal Validity .............................................................. 46

Remaining Threats to External Validity ............................................................. 48

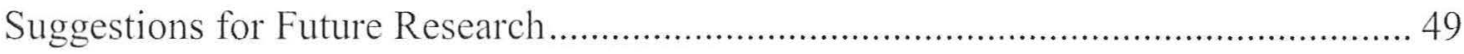

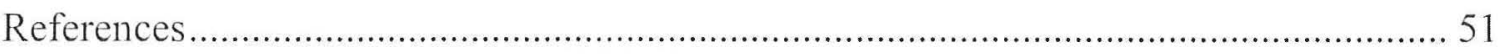

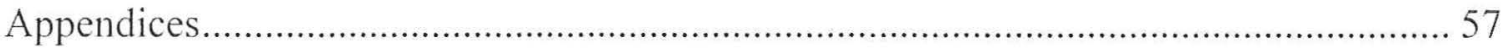

Appendix A: Administrators Consent Form .................................................. 57

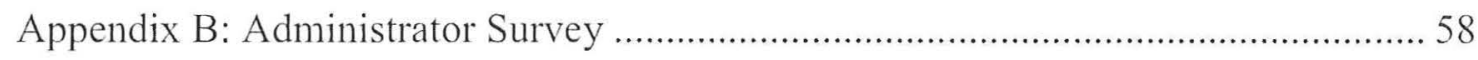

Appendix C: Survey Parental Consent Form ....................................................... 59

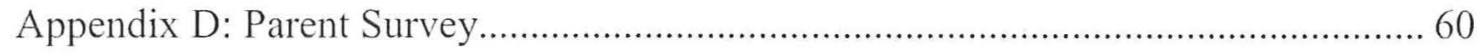

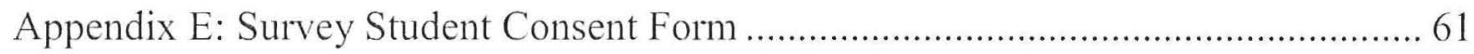

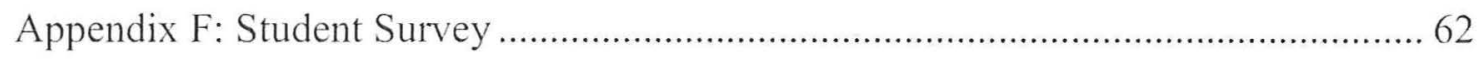

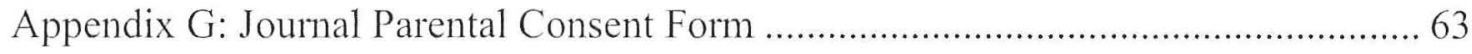

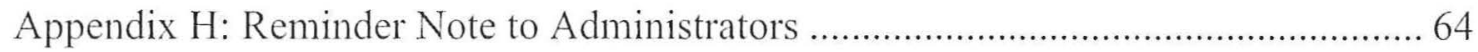




\section{BIBLE DEPARTMENT GENDER ISSUES}

\section{LIST OF TABLES}

Table

Page

1. Females should not teach Bible by respondent gender.............................................. 28

2. Females should not teach Bible by school size........................................................... 28

3. Females can teach female students by respondent gender ........................................ 29

4. Females can teach female students by school size ..................................................... 30

5. Females can teach male students by respondent gender ....................................... 31

6. Females can teach male students by school size.................................................... 32 
BIBLE DEPARTMENT GENDER ISSUES

\section{ACKNOWLEDGEMENTS}

I praise God for His sovereign plan in my life. He took the impossible and made a miracle. He has brought me to where I am today.

Special acknowledgment goes to my parents. For the last 30 years, they have prayed for me, given me advice, and supported me in so many ways throughout my education. Thank you.

I especially want to thank Tyler Spata. He has cheered me on when I needed it most. His prayers, support, and advice have been invaluable. Thank you for challenging and encouraging me through this process.

I would like to thank Dr. Gary Kennedy for the countless hours of advice he gave me. He believed in me when others did not. Thank you for analyzing my data and guiding me through the writing process. 


\section{BIBLE DEPARTMENT GENDER ISSUES}

\section{Chapter 1: Introduction}

The Bible and Bible classes are common entities found in Christian schools. During the mid 1960s, the Christian school movement experienced a rapid growth due to the secularization of public schools through Supreme Court cases; this growth has continued through today to an estimated 1.2 million students enrolled in America's Christian schools (Green, 2006). Of the six million students enrolled in private schools, $20 \%$ of these students attend private Christian schools (Boerema, 2011).

The title "Christian" does not necessarily mean students attending Christian schools are exempt from experiencing the same struggles faced by their counterparts enrolled in public schools. A comparative study analyzed school moral behavior between Christian school students and public school students and found no statistically significant difference between the two groups in regards to school moral behavior (Jeynes, 2009). Today, teenagers in America face violence, broken homes, and depression, along with the pressure of drugs, alcohol, sex; female adolescents also face the pressure of beauty and image (Bruce \& Cockreham, 2004).

Studies have shown students often confide in their teachers about the problems and issues they face (Boldero \& Fallon, 1995; Carrington, Tymms, \& Merrell, 2008). Students benefit from an individual who offers them a sense of community, affirms their abilities, and gives them the confidence and strength to meet the challenges of life (Parks, 
BIBLE DEPARTMENT GENDER ISSUES

1991, p. 90). This belief supports the view of a teacher mentor who Cannister (1999)

described as an individual who provides security as he or she challenges and encourages a student to grow intellectually, spiritually, emotionally, physically and socially.

Carrington and Skelton (2003) stated that a mentor must earn the respect of the student, and the role of a mentor is to build up students' self-esteem, to help them meet their potential, and to address any problems that may arise.

When students begin confiding in their teachers with their problems, the question of gender matching between teachers and students arises. Studies regarding general education in primary schools have found students may not be concerned with a teacher's gender as much as they are concerned with the teacher's ability to teach (Francis et al., 2008). Driessen (2007) found similar results in a study of Dutch primary schools; however, he stated the secondary-school situation is different because there are more males teaching at this level.

While gender may not matter regarding teaching, Driessen (2007) found students in secondary schools were shyer around teachers of the opposite sex. Francis et al. (2008) interviewed one boy about gender matching, and the boy said he preferred talking with a male teacher because the male understood what the boy was going through because of their same gender. In another study, a student stated a preference for talking with a teacher of the same sex when it came to discussing personal matters (Carrington et al., 2008).

When students begin confiding their problems to their teachers, another area of exploration is ethical boundaries. In a study of primary and secondary level teachers, Barrett, Headley, Stovall, and Witte (2006) found some teachers believe they need a 
BIBLE DEPARTMENT GENDER ISSUES

national, enforceable code of ethical conduct in order to protect themselves and students because they do see misconduct in romantic relationships between other teachers and students. In a study on the college level, where professors are sometimes encouraged to interact with students outside of the classroom, students stated they saw cross-gender interactions as more unethical than same-gender interactions, such as the interaction between a female professor and a female student (Oldenburg, 2005).

Women mentoring or teaching other women is not a new concept; however, some academic, evangelical settings hold to the belief that women should not teach the Bible to men, and women are restricted on what they can and cannot do in a religious setting (Lewis Hall, Christerson, \& Cunningham, 2010). MacArthur (1996) wrote that the Bible forbids women to teach men (p. 78). However, in the New Testament Church, older women were responsible for teaching children and younger women what was good, noble, holy, and godly (MacArthur, 1996, p. 78). Paul writes:

Likewise, teach the older women to be reverent in the way they live, not to be slanderers or addicted to much wine, but to teach what is good. Then they can urge the younger women to love their husbands and children, to be self-controlled and pure, to be busy at home, to be kind, and to be subject to their husbands, so that no one will malign the word of God. (Titus 2:3-5, New International Version) Through the teaching and instruction of the Bible, older women are likely to influence younger women's actions and thoughts (Peace, 1997, p. 31). According to MacArthur (1996), women have the responsibility to teach children and younger women in both formal settings, such as a school, and informal settings (p. 78). Paul told Titus to instruct 
BIBLE DEPARTMENT GENDER ISSUES

the older women to encourage and teach younger women sound doctrine and character

(Peace, 1997, p.3)

\section{Definition of Terms}

This section defines terms used in this research study.

Christian School - This refers to a category of private schools that supports a biblical education, advances Christianity, and teaches and encourages students to know and obey God as they prepare for life (Boerema, 2011). The category consists of schools that are theologically conservative, protestant, and evangelical (Green, 2006).

Adolescents - This refers to the time span of development that begins when individuals have reached puberty and ends when they reach the threshold of adulthood where, at this point, they finally take responsibility for their own actions and direction in life (Parks, 2001, p. 76-77).

Boundaries -This refers to the action of constraining and limiting (Aultman, Williams-Johnson, \& Schutz, 2009).

Gender Matching - This refers to when the sex of a teacher aligns with the sex of the student (Francis et al., 2008).

Evangelical -This refers to a form of conservative Christianity that engages with society while still maintaining a biblical identity (Lewis Hall et al., 2010).

Teacher Mentor-An individual who directs, supports, challenges, and helps students reach their academic and everyday life dreams (Cannister, 1999).

Mentor - This is an individual who becomes a confidant and guide to a younger person by developing and investing in a personal relationship with them (Georgiou, Demetriou, \& Stavrinides, 2008). Learners or students receive one-on-one instruction 


\section{BIBLE DEPARTMENT GENDER ISSUES}

from mentors where they are encouraged in their personal growth and development (Cannister, 1999).

Gender Harassment - This refers to any treatment that puts people at a comparative disadvantage to other groups because of their sex (Lewis Hall et al., 2010).

\section{Statement of Issue}

Female adolescents experience a wide variety of issues and problems in their everyday lives and often seek guidance from their teachers (Bruce \& Cockreham, 2004). As such, there is a need to survey the Bible department staff make-up of Christian schools to see if women are in the department to listen and to guide girls. Gender matching, specifically within Bible departments of Christian schools, is an issue that has not been widely studied. Many students have said they prefer talking with a teacher of the same sex when discussing personal issues (Carrington et al., 2008). For this reason, there is a need to survey the perceptions individuals hold concerning female Bible teachers in Christian schools because some evangelicals believe women should not teach the Bible to men (Lewis Hall et al., 2010). In order to assess this belief, administrators, parents, and students in Ohio's Christian high schools will take a survey, answering questions regarding their perceptions of female Bible teachers, and students will write their perception of an all girls Bible class taught by a female.

\section{Scope of the Study and Delimitations}

In this study, I will survey the staff make-up of Christian school Bible departments and the perceptions of administrators, parents, and students concerning female, Bible teachers. The study will consist of 83 Christian high schools in Ohio. I 
BIBLE DEPARTMENT GENDER ISSUES

also will assess the perceptions of 17 junior and senior girls enrolled in an all girls Bible class.

\section{Significance of the Study}

With the issues and problems students face and the lack of an ethical code of conduct, it is imperative to consider safeguards that could easily be set in place through gender matching. In the Bible, the book of Titus speaks of the responsibility older women have to instruct the younger women (MacArthur, 1996, p. 78). For the main reasons of creating a secure environment for female adolescents and ethical boundaries for staff, it is necessary to research the staff make-up of Christian school Bible departments and the perceptions of female Bible teachers held by administrators, parents, and students. My study will do this.

The benefits of gender matching within Bible departments should be explored. Schools and administrators need to recognize the value of creating a safe, secure environment where female students can confide in female staff members within the Bible department, and they possibly need to reconsider certain structures within their school. For example, ethical standards may need to be examined; the school's staff make-up may need to be restructured; or other female staff members within the school may need to be available within the school to talk with female students. If schools and administrators view gender matching within the department as a needed component, then it should be encouraged and developed. As previously stated, gender matching has been studied on the secondary level where students have said they prefer working with teachers of the same sex when it comes to personal issues (Carrington et al., 2008; Driessen, 2007; Francis et al., 2008). However, these studies have not analyzed gender matching within 
BIBLE DEPARTMENT GENDER ISSUES

Bible departments. Thus, it is necessary to study the benefits of gender matching within Bible departments.

Theological beliefs are another element to consider in this study. Evangelical Christians tend to have the non-negotiable belief concerning gender roles that women should not teach the Bible to men (Lewis Hall et a1., 2010). In response to Titus 2, doctrinally sound women need to teach other women in a biblical manner (Peace, 1997, p. 19). The theological beliefs of administrators, parents, and students may differ throughout the schools studied.

The study will not only view the benefits of gender matching and differences concerning theological issues, but it will also identify areas for improvement within schools through surveys taken by administrators, parents, and students. The surveys ask whom female students confide in if there is not a female in the Bible department. If female staff members are not available, potential areas for improvement could be revealed to the school and to other schools in the study.

\section{Procedures}

Research questions

1. What is the staff make-up of Bible departments in Christian high schools in Ohio?

2. How do Ohio Christian school administrators, parents, and students view the position of females teaching Bible to high-school females?

3. If a Bible department at a Christian school in Ohio does not have a female staff member, do the female students have a female staff member they feel they can safely confide in with their personal, private concerns? 


\section{BIBLE DEPARTMENT GENDER ISSUES}

The action research will be conducted in a mixed method based on a dominant status concurrent design. I will specifically use a QUAN + qual design. The data will be collected through surveys created on SurveyMonkey (http://www.surveymonkey.com/). In addition, qualitative journals will be written. In analyzing the data, I will assess the staff make-up of Bible departments in Christian high schools and the views of administrators, parents, and students concerning female staff members teaching Bible. I also will look for areas of improvement for high school Bible departments to ensure a safe, secure environment is available where female students may confide their personal problems. 


\section{BIBLE DEPARTMENT GENDER ISSUES}

\section{Chapter 2: Literature Review}

\section{History of Religious Education and Private Christian Schools in America}

Historically, religion has been present throughout American education in various forms of moral and character education. Many of the early American colonists came to the New World with the desire to practice their religious and moral beliefs (Algera \& Sink, 2002). Initially, religious education was the primary purpose for early American schools, and these schools were under the control of the community churches (Passe \& Willox, 2009). The primary textbooks were the Bible and other readers that taught morality and ethics, such as McGuffey's Reader and Aesop's Fables (Algera \& Sink, 2002; Dawidowicz, 2003). The concept of moral development would continue through the end of the 19 th century.

American education in the 20th century went through three phases. At the onset, education focused on ethical codes of conduct; then, it moved toward a focus on moral education that was tolerant of individual beliefs; finally, in the 1990s, it focused on individual character attributes of students (Algera \& Sink, 2002). During the mid 20th century, the United States Supreme Court, in the cases of Engle v. Vitale in 1962 and Abington v. Schempp in 1963, deemed state required prayers and Bible reading unconstitutional in public schools (Jeynes, 2009; Watson, 2010; Wright, 1999). These events helped lead to the secularization of public schools; and, as a result, there was a move for the privatization of religious, Christian schools (Watson, 2010). 


\section{BIBLE DEPARTMENT GENDER ISSUES \\ Characteristics of Christian Schools}

The movement from public to private schools led to a rapid growth of private

Christian schools. In the mid 1960s, there were around 10,000 Christian schools; by the $1970 \mathrm{~s}$, the student population was an estimated 15,000; and by the mid 1990s, the enrollment was over one million students (Green, 2006). Watson (2010) wrote that Christian schools in Canada and America grew by 923\% between 1965 and 2008. During the 2009-2010 school year, 1,472,248 students were enrolled in 14,336 Christian schools in America (National Center for Education Statistics, 2011).

Even with the tremendous growth in Christian schools, there have been only a few studies on Christian schools, and these studies are dated (Uecker, 2008). The common thread running through these few studies of the schools is a Christ-centered, biblical education. Watson (2010) studied various private schools across the world and found all of the Christian schools he observed believe the Bible, or the inspired Word of God, applies to today's world. Boeream (2011) studied two groups of schools that represent most of America's evangelical schools: the Association of Christian Schools International (ACSI) and Christian Schools International (CSI). He discovered both of these groups have the common goal of teaching students about God and preparing the students for the world through Christian education (Boeream, 2011). Another study compared religious school sects and found that, while Christian schools were dedicated to integrating both religious and academic education, the primary focus was biblical instruction through Bible classes and chapel services (Uecker, 2008). 


\section{BIBLE DEPARTMENT GENDER ISSUES}

\section{Student Behaviors and Issues}

While very few studies exist on Christian schools, there are studies that look specifically at the behaviors of private school students and other studies that compare public and private school students. Smith (2003) stated that religiousness has an inverse effect on drug, alcohol, and tobacco use, and it also has an inverse effect on suicidal tendencies, depression, and hopelessness. In a survey of 160 middle and high school students' behavior where half the students went to public schools and the other half went to Christian schools, the teachers rated the students' behaviors in comparison to other students (Jeynes, 2009). The study found that while Christian school students were better behaved, the difference was not statistically significant (Jeynes, 2009). A study in Australia showed both public and Christian school students use cigarettes, alcohol, and marijuana; however, the Christian school students use these substances significantly less than their public school counterparts (Jones \& Rossiter, 2009). For example, 23\% of Christian school students use cigarettes; $52 \%$ use alcohol; and $8 \%$ use marijuana, while $58 \%$ of public school students use cigarettes; $93 \%$ use alcohol, and 38\% use marijuana (Jones \& Rossiter, 2009).

Tobacco products, alcohol, and drugs are not the only issues teenagers in general face. Adrian, Zeman, Erdley, Lisa, and Sim (2010) wrote that adolescents today struggle with anxiety, depression, and nonsuicidal self-injury (NSSI). By age 15, 4.1\% of males and $12.6 \%$ of females struggle with NSSI (Adrian et al., 2010).

Relationships can also cause stress in the lives of adolescents. Boldero and Fallon (1995) studied 1,013 secondary students with ages ranging from 11 to 18 years old, where 258 of the students stated their families had caused them significant distress in the 
BIBLE DEPARTMENT GENDER ISSUES

last six months. Over half of the students surveyed said they would ask for help; of the students who would ask for help, most of them were female (Boldero \& Fallon, 1995).

Bruce and Cockreham (2004) stated that adolescents are assaulted, neglected, sexually active, self-indulgent, and suicidal. Leonard and Scott-Jones' (2010) study of 118 high-school students in Boston revealed serious romantic relationships were more likely than religious restrictions to determine adolescents' sexual behavior for threefourths of the male and female seniors. While $69 \%$ of the seniors in this study said they apply religious beliefs to their lives, $76 \%$ of the males and $72 \%$ of the females stated they were more likely to have sexual intercourse if they were in a serious relationship (Leonard \& Scott-Jones, 2010).

With a sexualized and image driven culture, many adolescents are trying to find meaning in their lives (Bruce \& Cockreham, 2004). A study of 683 eighth and ninth graders, $49 \%$ of which self-identified as Protestant, revealed the females have higher levels of depression than males (Milot \& Ludden, 2009). Additionally, suicide is the third leading cause of death among 15 to 24 years-old in the United States, with females more likely to attempt suicide than males (Maimon \& Kuhl, 2008).

\section{Teacher Mentor}

Students in a religious institution are less likely to participate in substance abuse because the institution with which they are involved provides them with adults other than their parents who help support and encourage them (Georgiou et al., 2008; Milot \& Ludden, 2009). A slightly older study of college freshmen, conducted by Cannister (1999), demonstrated that a teacher mentor is most effective in a group community both inside and outside the classroom. Within a Christian school setting, mentoring that 
BIBLE DEPARTMENT GENDER ISSUES

occurs in a group setting is more spiritually effective than one-on-one mentoring because groups help create a sense of belonging (Parks, 1991, p.89).

Mills (2003) stated that mentors in the academic setting are to teach and model Biblical values clearly in the school community and classroom. It is in this Christcentered community that students' moral and character development occurs because the students watch and emulate the examples of their teachers who daily model Christian character to them (Algera \& Sink, 2002). Smith (2003) observed that once the student established this type of relationship with a teacher, the student begins calculating the cost of violating moral order because he or she wants to maintain a healthy relationship.

Through the relationship of modeling, teacher mentors should help lead their students through the process of confronting and evaluating society's issues from a biblical perspective (Mills, 2003). In this structured, modeled environment, teachers can challenge students to live out a Christian worldview (Van der Walt \& Zecha, 2004). Uecker (2008) observed that evangelical Christian schools stress the concept of integrated faith learning, or the belief that learning and Christianity are a part of and are applicable to the public sector in which students live and socialize.

In order for a mentoring relationship to develop, the mentor and mentee need to spend consistent and considerable time together in a respectful and caring environment (Aultman et al., 2009). Teachers cannot assume a mentoring relationship. Mentoring takes time and should be purposeful, honest, empathetic, and mutually respectful (Carrington \& Skelton, 2003; Georgiou et al., 2008).

More specifically, adolescent females need to feel emotionally connected in a mentoring relationship, so they may benefit from a relationship with a mentor that 
BIBLE DEPARTMENT GENDER ISSUES

stresses self-disclosure and compassion (Spencer \& Liang, 2009). The teacher mentor engages his or her student through wise, intellectual conversations that are genuine and sincere, and the teacher mentor must be willing to listen to the student (Van der Walt \& Zecha, 2004). As the result of being attentive to their students' needs, teacher mentors are able to correct and encourage their students to reflect on their actions and beliefs; in so doing, they may help their students develop morally (Algera \& Sink, 2002). Teacher mentors provide emotional support, which helps the student create a secure identity and find purpose and meaning in life (Bruce \& Cockreham, 2004). The mentor should not encourage the student to become just like the teacher; however, the mentor should create a curiosity in the students' lives that encourages them in their own personal journey (Cannister, 1999).

\section{Gender Matching}

Studies looking at the issue of gender matching have occurred in both the primary and secondary school setting. As previously stated, gender matching refers to aligning the sex of the teacher with the sex of the student; some believe students do better when there is a matched gendered relationship between the teacher and student (Francis et al., 2008). What is interesting, though, is that most of the studies done in primary school settings and some on the secondary level reveal the opposite: the sex of the teacher does not truly matter.

Francis et al. (2008), who studied 307 third-grade students at 51 schools in England, found that two-thirds of the students surveyed said a teacher's gender does not make a different because, regardless of gender, the teachers all teach the same thing. This same study included a survey for the teachers at the 51 schools and found half of the 
BIBLE DEPARTMENT GENDER ISSUES

teachers believed more things were at stake in education than gender matching; a teacher should teach in a calm and respectful environment (Francis et al., 2008). Female teachers do not necessarily create a suitable role model for girls and vice-versa; male teachers do not necessarily make the best role model for boys (Driessen, 2007). Another study surveyed 8,978, eleven year-old, primary students in 413 classes, where males taught 113 of the classes and females taught the other 300 classes (Carrington et al., 2008). The study found students were more likely to show positive attitudes in the classes taught by women (Carrington et al., 2008).

Driessen (2007) wrote the gender matching issue in a secondary school setting is very different from that of primary schools because there tend to be more males teaching in a secondary setting than in a primary school setting. In a study of 5,181 eighth-grade students and 251 of their teachers, teachers noted students are shyer around teachers of the opposite gender (Driessen, 2007). One boy said he preferred having a male teacher because a male would understand him (Francis et al., 2008). Another study reviewed the interviews of 12 adolescent females where the overwhelming statement from the girls was they could freely share anything with an older female because they knew she would listen to them and not reject them (Spencer \& Liang, 2009).

\section{Ethical Boundaries}

\section{Examples of Misconduct}

As teachers and students form relationships in the education field, it is important to view ethical boundaries in order to avoid gender harassment. According to Barrett, Headley, Stovall, and Witte (2006), when comparing the education field with other service professions, such as the medical and psychological fields, an ethical code of 
BIBLE DEPARTMENT GENDER ISSUES

conduct is missing from the education field. This is significant considering the recent criminal cases of teacher misconduct with students.

For example, Archibald (2004) wrote that over 4.5 million students, from kindergarten to 12 th-grade, were victims of sexual misconduct by school employees between 1994 and 2004. In a 2000 study of reported sex offenders in schools, $57.2 \%$ of offenders were men, and 42.8\% were women (Archibald, 2004). In all of these cases, violations of boundaries put the students at risk emotionally and physically (Barrett et al., 2006). Even in the last year, Ohio has seen its share of teacher sexual misconduct offenders.

A female gym teacher in Mason, Ohio, faced 16 felony counts of sexual battery with five high-school boys (Richter, 2011). A Cleveland, Ohio, female teacher was sentenced for having an improper relationship with a 14-year-old male student, phoning and texting him around 4,000 times (Sangiacomo, 2011). Most recently, a male middleschool teacher in Lancaster, Ohio, was charged with three counts of sexual conduct with a 15-year-old girl (Burnett, 2011; Ludlow, 2011).

\section{Teachers and Students Rate Teachers}

Barrett et al. (2006) surveyed 2,000 school personnel in South Carolina; of the 235 staff members who responded, 47 were male teachers, and 137 were female teachers. They found that $94.1 \%$ of the respondents believed an ethical violation of teachers included teachers engaging in romantic relationship with students and teachers discussing highly personal subjects with students (Barrett et al., 2006). Another study interviewed 13 in-service teachers who stated that with the extensive period of time, conversation, sensitivity, and respect that teacher mentoring requires, it is extremely important to find a 
BIBLE DEPARTMENT GENDER ISSUES

healthy balance between caring for the student while not getting carried away (Aultman et al., 2009).

A study similar to the previous two took place on college campuses. Oldenburg (2005) found professors are encouraged to be friends with their students and be involved in the students' lives outside of class; as a result, many professors are concerned with unwarranted charges of sexual harassment. What was interesting about this study was students found cross-gender interactions between professors and students to be more unethical than the female-female relationships between professors and students (Oldenburg, 2005).

\section{Theological Issues}

In some academic evangelical settings, females face gender harassment because of the belief that some hold that women should not teach the Bible to men, so women are restricted on what they can and cannot do in a religious setting (Lewis Hall et al., 2010). Johnson (2011) wrote that some faiths use New Testament passages, such as Ephesians 5:23-30, I Corinthians 11:3-9, and I Timothy 2:11-15, to identify the role of women within the church. However, the passage in Ephesians refers to the relationships between Christ and man and a husband to his wife; I Corinthians refers to public worship; and I Timothy states women should not have authority over men (Johnson, 2011).

In Titus, Paul specifically addressed the issue of women teaching or mentoring other women:

Likewise, teach the older women to be reverent in the way they live, not to be slanderers or addicted to much wine, but to teach what is good. Then they can urge the younger women to love their husbands and children, to be self-controlled 
BIBLE DEPARTMENT GENDER ISSUES

and pure, to be busy at home, to be kind, and to be subject to their husbands, so

that no one will malign the word of God. (Titus 2:3-5)

Peace (1997) claimed older women have the ability to influence younger women's thoughts and actions (p. 31). Older women should pray for the younger women and involve them in their lives in the classroom (Peace, 1997, p. 50). In the church, older women are responsible for teaching children and younger women those things that are good, noble, holy, and godly (MacArthur, 1996, p. 78). Peace (1997) stated the older women are to teach sound doctrine, character, and ministry for God (p. 3). The older woman depicted in Titus 2 was a woman the elders in the early church could depend upon to be a godly influence on the younger women because she was mature in her faith and continued to seek God's wisdom (Peace, 1997, p. 44).

\section{Summary}

This review of literature highlighted the history of Christian education and the mentoring and teaching that occurs within the walls of a school. It observed the relationship between teachers and students and the delicate balance educators must maintain in addressing the issues high-school students face. More specifically, it addressed the theological issue of women teaching the Bible in a Christian school.

With the many issues that students, particularly females, face and the ethical boundaries of teachers, it is crucial to study the Bible staff make-up of high-school Christian schools. When it comes to personal matters, students prefer talking with teachers of the same sex (Carrington et al., 2008). Uecker (2008) found that Christian schools were dedicated to integrating both religious and academic education; however, the primary focus of Christian schools was biblical instruction through Bible classes and 
BIBLE DEPARTMENT GENDER ISSUES

chapel services. Throughout studies of American secondary schools, the study of the staff make-up of Bible departments in Christian schools has not been conducted, to date. Therefore, this study focuses on examining administrators, parents, and students' perceptions of female Bible teachers in Ohio's Christian schools to see if female students have a teacher or another person with whom they can feel safe disclosing information about the personal issues they face. 
BIBLE DEPARTMENT GENDER ISSUES

\section{Chapter 3: Methodology}

For this study, action research was performed using a mixed method based on a dominant status concurrent design. I specifically used a QUAN + qual design. The goal was to examine the Bible department staff make-up in Ohio Christian high schools, to examine administrator, parents, and students' views about females teaching Bible, and, finally, to see if female students have an individual with whom they feel they can safely confide.

In order to accomplish this goal, administrators from Ohio Christian schools received a consent form (see appendix A) and survey. (See appendix B). Administrators were asked to forward another survey on to parents (see appendix C), which included a letter of consent. (See appendix D). Then, parents were asked to send a third survey (see appendix E) to their student, which also included a consent form. (See appendix F). The surveys were open for four weeks. The survey for administrators consisted of 12 questions; the parent survey had six questions; and the student survey included eight questions. Only one school administrator sent the parent survey to parents; subsequently, the student surveys were only sent to students at one school. The surveys were then collected and statistically analyzed.

At the same time, the students enrolled in the all girls Bible class that I teach wrote about their experience in their journals. They responded to two questions, describing what they liked and did not like about the class. I then asked them to describe what they would change about the class. 


\section{BIBLE DEPARTMENT GENDER ISSUES}

\section{Rationale for the Method}

Johnson and Christensen (2004) wrote that action research is a form of research often used by educators because it focuses on solving specific problems (p. 9). Mixed method research involves combining both quantitative and qualitative research methods. A dominant status concurrent design of QUAN + qual design means the main portion of the study is the quantitative phase because more quantitative data was collected than qualitative data at concurrent or approximately the same time (Johnson \& Christensen, 2004, pp. 418-419). In this study, the survey data were quantitative, and the student journals were qualitative. The study focused on the educational problem of staff genders of Bible departments in Christian high schools in Ohio, specifically on the perceptions of female Bible teachers held by administrators, parents, and students.

Research has been conducted on gender matching and on perceptions of women teaching the Bible; however, studies analyzing the staff make-up of Bible departments in Christian schools have not been conducted, to date. I wanted to know the Bible staff make-up of Ohio's Christian schools and the perceptions held by administrators, parents, and students concerning women teaching the Bible. The means I used for accomplishing this goal was through a mixed method based on a dominant status concurrent design, specifically a QUAN + qual design.

\section{Population of the Study}

The population of the study consisted of administrators of Christian schools in Ohio, parents who send their students to these schools, and high school students who attend the schools. The results of the study may be applicable to Christian schools, specifically to the Christian schools in Ohio and perhaps to those in the United States. 


\section{BIBLE DEPARTMENT GENDER ISSUES}

\section{Rationale for Population}

The sample focus came from Ohio schools because there is a wide variety of size and theological beliefs in Ohio Christian schools. Administrators were used for this research because they are the voice of their schools, and they oversee the philosophy of their schools. Parents were used because they ultimately choose to send their students to Christian schools. Surveyed students were used to determine if they had a teacher of the same sex with whom they could confide. Student perceptions were gathered because the students who responded currently participate in an all girls Bible class taught by a female. The class was easily accessible because it is the Bible class I teach.

\section{Description of the Sample}

The participants used in the quantitative stage of this research study were 83 administrators in Ohio Christian schools. Of the 83 administrators, 39 took the survey; however, two administrators answered only 3 of the 12 questions. The distribution of ages for administrators across the brackets is the following: $30-39$ years old: $5.4 \% ; 40-49$ years old: $27.0 \%$; 50-59 years old: $45.9 \%$; and 60-69 years old: $21.6 \%$. Eleven women $(29.7 \%)$ took and completed the survey. Twenty-eight men started the survey; however, only $26(70.3 \%)$ completed it.

Administrators were asked to forward a parent survey to the parents of the students in their school; however, only one administrator did this. As a result, 47 parents responded to the survey. The distribution of ages for parents across the brackets is the following: $30-39$ years old: $12.8 \%$; 40-49 years old: $55.3 \%$; $50-59$ years old: $29.8 \%$; and 60-69 years old: $2.1 \%$. Thirty-nine females (83.0\%) and eight males $(17.0 \%)$ took this survey. 
BIBLE DEPARTMENT GENDER ISSUES

The parents forwarded the student survey to their student, and 17 students ended up taking the student survey. Eight females (47.1) and nine males (52.9\%) took the survey, ranging from six 9 th grade students $(35.3 \%)$, three 10 th grade students $(17.6 \%)$, five 11 th grade students $(29.4 \%)$, and three 12 th grade students $(17.6 \%)$.

The participants used in the qualitative stage of this research study were 17, eleventh and twelfth grade students in my all girls Bible class. Fourteen of the 17 girls' guardians signed letters of consent. (See appendix G). Of the 14 girls, six were in 11 th grade, and eight were in 12 th grade. Thirteen of the students $(92.9 \%)$ were Caucasian, and one was African American.

\section{Methods of Sampling}

Samples for the first phase of the study, the quantitative survey, were collected through on-line surveys. These surveys were sent to Ohio Christian school administrators who had email access. The administrators of the schools were then asked to forward a survey link to parents of students within their school; however, as previously stated, only one administrator did this. Parents were then asked to send the student survey link to their students. The second phase of sampling, the qualitative survey, occurred in my all girls Bible class. The students wrote about their perceptions of the class in their journals.

\section{Procedure}

\section{Instruments}

The instruments used in the quantitative phase of this study were surveys designed on SurveyMonkey (http://www.surveymonkey.com/). This website then sent emails to the 83 administrators containing a link to the survey for administrators. 
BIBLE DEPARTMENT GENDER ISSUES

Administrators, parents, and students were told the survey would be open for four weeks. After the end of the second week, a reminder to take the survey was sent to the administrators of the schools. (See appendix H). After four weeks, the survey results were collected and analyzed.

The instruments used in the qualitative phase of this study were journals. The girls Bible class answered the following prompts:

1. What do you like about this class?

2. What did you not like about this class?

3. What would you do to improve this class?

The responses were copied, typed, and handed back to the students, so they could check the transcription to ensure accurate data collection.

\section{Data Collection Methods}

Two main types of data collection were used: surveys and journals. Surveys were given to administrators, parents, and students. The researcher gave the all girls class prompts for their journal entries, and the girls wrote their responses. The prompts were written on the chalkboard in the classroom and the researcher asked the students to answer honestly the three questions written on the board in their journals.

\section{Relevant Ethical Considerations}

Administrators, parents, and students agreed to the consent form attached to the beginning of the survey, with the understanding that their answers would remain anonymous, and they could withdraw from the study at anytime. Some administrators who took the survey sent additional comments about the study. These individuals were given pseudonyms as a means of keeping their identities confidential. Permission was 
BIBLE DEPARTMENT GENDER ISSUES ·

obtained from the legal guardian of each student before the student surveys were taken because the guardian had the choice to forward or not to forward the student survey link to their student. Permission was obtained from the school's principal to perform the qualitative phase of the study (the journals). Permission was then obtained from the legal guardian of the girls in the Bible class before data were analyzed and presented in this paper. Students were given the opportunity to opt out of the study by not returning the consent form. Students in this qualitative phase of the study were given pseudonyms as a means of keeping their identities confidential.

\section{Methods of Data Analysis}

Non-parametric tests and tests of concordance and proportions were conducted using Minitab, Version 16 (2010). The journal entries were collected and copied, and the originals were handed back to the students. After making copies, the entries were typed and handed back to the students, so they could check the transcription to ensure accurate data collection. The entries were then assigned a number correlating with the student's pseudonym. Entries were then typed and organized according to question. The data analysis of the journal entries involved comparative analysis. Recurring themes were compared throughout the data. This resulted in a list common of themes. 


\section{Chapter 4: Results Quantitative Results}

The return rate for the administrators who completed their survey in this study was $44.6 \%$. Through an email sent using the website SurveyMonkey, the researcher contacted 83 Christian school administrators, requesting their participation in the study. Thirty-nine of the administrators responded; however, only 35 fully completed the survey; one male administrator did not answer two questions, and another male did not answer one question.

Administrators were asked to forward a parent survey, created on SurveyMonkey, to the parents of their school. One school complied with the request; and, as a result, 47 parents took the parent survey.

Parents were also asked to forward a student survey, also created on SurveyMonkey, to their student. Seventeen students took the survey.

\section{Quantitative Results: Administrators}

The administrators' survey sampled 37 schools that, collectively, had 4,013 students in attendance. The smallest school surveyed had four students enrolled, and the largest school had 498 students enrolled. The average enrollment of the high schools was 117 students. The administrators' survey addressed the first research question, the staff make-up of Bible departments. Of the 37 schools surveyed, 19 schools (51.4\%) had female Bible teachers. The sample consisted of 2,012 boys (50.1\%) and 2,001 girls (49.9\%). However, there were 74 male teachers (71.8\%) and only 29 female teachers 
BIBLE DEPARTMENT GENDER ISSUES

$(28.2 \%)$. In a test comparing two proportions, the proportion of female teachers was significantly less than the proportion of female students $(z=4.82, p<.0001)$.

A comparison between each school's ratio of female teachers to female students and male teachers to male students found the median ratio of female teachers to female students was .008 , about one teacher per 100 students. However, the median ratio of male teachers to male students was .052, about five teachers per 100 students. Using the non-parametric Mann-Whitney test for the comparison of medians, this difference was statistically significant $(\mathrm{W}=854.5, \mathrm{p}<.0001)$.

For the second research question, a series of three statements was given to administrators, who rated their response or perception by strongly disagree, disagree, agree, or strongly agree. The three statements were the following: females should not teach Bible; female staff members can teach female students the Bible; and female staff members can teach male students the Bible.

In the first statement, females should not teach Bible, the results were analyzed by respondent gender, of which 11 respondents (29.7\%) were female, and 26 respondents $(70.3 \%)$ were males. Thirty-three of the administrators disagree or strongly disagree with this statement. No female administrators agree with the statement; however, four male administrators did agree with it. The test of concordance (Somer's D =.346) was statistically significant, $\mathrm{p}=.032$ (see Table 1$)$.

These school sizes were then analyzed based on the administrators' answers. Fourteen of the administrators disagree with the statement; 19 strongly disagree with the statement; and four agree with it. Of the administrators who agree, two of their schools have an enrollment of less than 100 students, and the other two have schools with 250 or 


\section{BIBLE DEPARTMENT GENDER ISSUES}

more students. The corresponding test of concordance (Somer's D $=.073$ ) was not statistically significant, $\mathrm{p}=.330$. There is thus no evidence to suggest a statistically significant relationship between school size and attitude regarding whether women should teach Bible (see Table 2).

Table 1

Females Should Not Teach Bible by Respondent Gender

\begin{tabular}{lccc}
\hline Perceived Attitude & Female & Male & Total \\
\hline Strongly Disagree & 8 & 11 & 19 \\
Disagree & 3 & 11 & 14 \\
Agree & 0 & 4 & 4 \\
Strongly Agree & 0 & 0 & 0 \\
\hline Total & 11 & 26 & 37 \\
\hline
\end{tabular}

Table 2

Females Should Not Teach Bible by School Size

\begin{tabular}{|c|c|c|c|c|c|c|c|}
\hline \multicolumn{8}{|l|}{ Perceived Attitude } \\
\hline & \multicolumn{6}{|c|}{ Ranked School Size } & \multirow[b]{2}{*}{ Total } \\
\hline & 1 & 2 & 3 & 4 & 5 & 6 & \\
\hline Strongly Disagree & 4 & 5 & 3 & 3 & 2 & 2 & 19 \\
\hline Disagree & 6 & 2 & 3 & 1 & 2 & 0 & 14 \\
\hline Agree & 1 & 1 & 0 & 0 & 0 & 2 & 4 \\
\hline Strongly Agree & 0 & 0 & 0 & 0 & 0 & 0 & 0 \\
\hline Total & 11 & 8 & 6 & 4 & 4 & 4 & 37 \\
\hline
\end{tabular}




\section{BIBLE DEPARTMENT GENDER ISSUES}

The results of the second statement, female staff members can teach female students the Bible, were analyzed by respondent gender. Of the 36 respondents, 11 respondents $(30.6 \%)$ were female, and 25 respondents $(69.4 \%)$ were males. One of the four male administrators who agreed with the Statement 1 did not answer this question. Thirty-two administrators agree or strongly agree with this statement. Two female administrators and two male administrators disagree or strongly disagree with the statement. The two male administrators who disagree with this statement disagreed with Statement 1; females should not teach the Bible. The corresponding test of concordance (Somer's $\mathrm{D}=.084$ ) was not statistically significant, $\mathrm{p}=.269$. There is no evidence to suggest a statistically significant relationship between respondent gender and attitude regarding whether women should teach Bible to girls (see Table 3).

Table 3

Females Can Teach Female Students by Respondent Gender

\begin{tabular}{lccc}
\hline Perceived Attitude & Female & Male & Total \\
\hline Strongly Disagree & 2 & 1 & 3 \\
Disagree & 0 & 1 & 1 \\
Agree & 2 & 12 & 14 \\
Strongly Agree & 7 & 11 & 18 \\
\hline Total & 11 & 25 & 36 \\
\hline
\end{tabular}

These results were then analyzed by school size based on the administrators' answers. Thirty-two of the school administrators agree or strongly agree, and four school administrators with school enrollments of 200 or less students agree or strongly agree 
BIBLE DEPARTMENT GENDER ISSUES

with the statement that female staff members can teach female students. The

corresponding test of concordance (Somer's D =.094) was not statistically significant, $p$

$=.286$. There is no evidence to suggest a statistically significant relationship between

school size and attitude regarding whether women should teach Bible to girls (see Table

4).

Table 4

Females Can Teach Female Students by School Size

\begin{tabular}{|c|c|c|c|c|c|c|c|}
\hline \multicolumn{8}{|l|}{ Perceived Attitude } \\
\hline & \multicolumn{6}{|c|}{ Ranked School Size } & \multirow[b]{2}{*}{ Total } \\
\hline & 1 & 2 & 3 & 4 & 5 & 6 & \\
\hline Strongly Disagree & 1 & 0 & 1 & 1 & 0 & 0 & 3 \\
\hline Disagree & 0 & 1 & 0 & 0 & 0 & 0 & 1 \\
\hline Agree & 4 & 3 & 4 & 0 & 2 & 1 & 14 \\
\hline Strongly Agree & 5 & 4 & 1 & 3 & 2 & 3 & 18 \\
\hline Total & 10 & 8 & 6 & 4 & 4 & 4 & 36 \\
\hline
\end{tabular}

Note. The range of school sizes range from category 1: 1-49 students, 2: 50-99 students, 3:100-149 students, 4: 150-199 students, 5: 200-249 students and 6:250+ students.

The results of the third statement, female staff members can teach male students the Bible, were analyzed by respondent gender. Thirty-five administrators, 11 females (31.4\%) and 24 males (68.6\%), responded. Of the two male administrators who did not respond to this statement, one of them also did not answer Statement 2 and the other male disagreed with Statement 2. Thirty administrators (85.7\%) agree or strongly agree with the statement. One female administrator and four male administrators disagree or strongly disagree with the statement. The female administrator who disagrees with the 
BIBLE DEPARTMENT GENDER ISSUES

statement only disagrees rather than strongly disagrees. Only one male administrator who disagrees with Statement 2, also disagrees with this statement, female staff members can teach male students the Bible.

The corresponding test of concordance (Somer's D $=.215$ ) was marginally statistically significant, $p=.054$. This result has to be interpreted with caution, but the marginal significance may be due to the data suggesting that the odds of women administrators agreeing or strongly agreeing that women can teach boys the Bible are approximately two times greater than the corresponding odds for male administrators (see Table 5).

Table 5

Females Can Teach Male Students by Respondent Gender

\begin{tabular}{lccc}
\hline Perceived Attitude & Female & Male & Total \\
\hline Strongly Disagree & 0 & 2 & 2 \\
Disagree & 1 & 2 & 3 \\
Agree & 3 & 12 & 15 \\
Strongly Agree & 7 & 8 & 15 \\
\hline Total & 11 & 24 & 35 \\
\hline
\end{tabular}

The analysis by school size based on the administrators' answers shows the corresponding test of concordance (Somer's $D=.268$ ) was statically significant, $p=.050$. This result appears to occur because no administrator in schools with enrollments greater than or equal to 150 students disagrees or strongly disagrees with this attitude (see Table 6). 
BIBLE DEPARTMENT GENDER ISSUES

Table 6

Females Can Teach Male Students by School Size

\begin{tabular}{lccccccc}
\hline Perceived Attitude & \multicolumn{7}{c}{ Ranked School Size } \\
\cline { 2 - 6 } & 1 & 2 & 3 & 4 & 5 & 6 & Total \\
\cline { 2 - 6 } Strongly Disagree & 2 & 0 & 0 & 0 & 0 & 0 & 2 \\
Disagree & 2 & 0 & 1 & 0 & 0 & 0 & 3 \\
Agree & 2 & 5 & 4 & 1 & 2 & 1 & 15 \\
Strongly Agree & 4 & 3 & 1 & 3 & 2 & 2 & 15 \\
\hline Total & 10 & 8 & 6 & 4 & 4 & 3 & 35 \\
\hline
\end{tabular}

Note. The range of school sizes range from category 1: 1-49 students, 2: 50-99 students, 3:100-149 students, 4: 150-199 students, 5:200-249 students and 6:250+ students.

\section{Quantitative Results: Parents}

The parents' survey also asked parents their view on the position of females teaching the Bible. Question five of their survey asked parents if they preferred their female student to discuss her problems and issues with a male or female Bible teacher. Of the 47 parents who took the survey, 39 respondents (83.0\%) were female, and 8 respondents $(17.0 \%)$ were male. Based on their responses, there was no statistically significant relationship between the gender of the parent and the preference for the gender of a Bible teacher (Fisher's exact test, $\mathrm{p}=.322$ ).

Collapsed across the gender of the parent, 34 of the 44 parents (77.3\%) who answered question five prefer a female Bible teacher for girls. This represented a statistically significant majority (i.e. greater than $50 \%, \mathrm{p}<.0001$ ). 


\section{BIBLE DEPARTMENT GENDER ISSUES}

Question six on the parent survey asked parents about their preference of an all girls Bible class for their daughter. There was no statistically significant relationship between the gender of the parent and the desire for an all girls Bible class (Fisher's exact test, $\mathrm{p}=.502)$. However, collapsed across the gender of the parent, 35 of the 39 parents (89.7\%) who answered question six prefer an all girls Bible class. This represented an overwhelming statistically significant majority (i.e. greater than $75 \%, \mathrm{p}<.0001$ ).

\section{Quantitative Results: Students}

The student survey answered the third research question. Seventeen students, eight females (47.1\%) and nine males (52.9), took the survey. They were asked if they would feel comfortable confiding in a male or female teacher. Of the 17 students, only one $(5.9 \%)$ had a female Bible teacher.

Five out of eight female students $(62.5 \%)$ and nine out of nine male students reported feeling comfortable confiding in a male teacher. This relationship has to be interpreted with caution, but the relationship is marginally statistically significant (Fisher's exact test, $\mathrm{p}=.082$ ).

However, seven out of eight female students (87.5\%) and seven out of nine male students $(77.8 \%)$ reported feeling comfortable confiding in a female teacher. This relationship was not statistically significant (Fisher's exact test, $\mathrm{p}=1.000$ ).

While these results may suggest a gender preference, the sample is too small and the power too low (power is .326 for this sample size) to detect a difference.

When specifically asked the sex of the teacher with whom the student confides, six out of eight female students (75.0\%) and eight out of nine male students $(88.9 \%)$ said they confide in a staff member of the same sex. This relationship was not statistically 
BIBLE DEPARTMENT GENDER ISSUES

significant (Fisher's exact test, $\mathrm{p}=.576$ ). However, a majority (greater than $50 \%$ ) of

students $(82.4 \%)$ did report confiding in an adult of the same sex $(p=.008)$.

If female students did not have a Bible teacher of the same sex, the students said they confide in other teachers and counselors of the same sex.

\section{Qualitative Results}

To measure the perceptions of an all girls Bible class taught by a female, journal prompts were given to 17 female students enrolled in an all girls class. The prompts focused on the girls' perception of the class and their suggested areas for improvement. Of the 17 girls, 14 of their guardians (82.4\%) signed the consent form. The 14 journal entries were transcribed and handed back to the students to check for accuracy; then each girl's entry was assigned a number that correlated with the student's pseudonym. Through comparative analysis of the entries, common themes emerged.

\section{Common Themes}

The most overwhelming theme from 12 of the 14 girls $(85.7 \%)$ was they like the concept of an all girls Bible class taught by a female. Jane, a senior, wrote, "It's nice to have a female teacher rather than a male teacher for Bible class because we can talk about other things and be more specific with topics and things like that." Sara, a junior, reflected on her previous experiences with a male Bible teacher, and she commented on the fact she could not be real with him because it was awkward sharing her thoughts with him. Kate, a junior, wrote, "I liked that we were able to open up and talk about a lot of stuff that you can't in other classes because we are all girls." Five of the girls said they feel they could be more real and honest with themselves and each other in an all girls environment. The other themes revolved around this main concept of an all girls class. 


\section{BIBLE DEPARTMENT GENDER ISSUES}

Eight of the girls wrote the class provided them with a safe environment to

discuss the various issues they face as female adolescents. Kate wrote, "I think the issues in teen girls' lives that we talked about were good." Combined, the girls listed 31 issues with which they struggle. Dating, boundaries in relationships, rape, pornography, sex, sexually transmitted diseases, pregnancy, and self-image are just samples of the issues the girls wrote about in their journal entries. Jane wrote about this freedom:

It's nice to have a female teacher rather than a male teacher for Bible class, because we can talk about other things and be more specific with topics and things like that. I really trust my teacher and am comfortable opening up to her and coming to her for advice and I know I can ask her about anything.

Eight of the girls focused on their spiritual walk with God. In the class, they feel comfortable sharing where they are in their walk, and they know they will not be judged by the other girls. Anne, a junior, wrote the following:

I really enjoyed that a group of girls can get together and talk openly about girls and guys and sexual sin. I like how we can be mature about and not hide from it.

I like how we can all share our different opinions and not be judged.

One of the girls wrote about the issues she was experiencing in her life, noting how the conversations in the class caused her to be real and honest with herself and others. She then stated she needs to put Christ first before any other relationship.

Eight of the 14 girls (57.1\%) wrote about their self-images prior to entering the class, stating their self-images were poor because they believed the lies of the world that they were not good enough. However, as they took the class, they began to view 
BIBLE DEPARTMENT GENDER ISSUES

themselves as the daughters of God and to believe His opinion of them alone was what mattered. Liz, a senior, wrote about this change:

I liked the realness of this class. I think a lot of times certain subjects are pushed aside in hopes that someone else will address them. I liked the emphasis on how we are the Bride of Christ and we are special despite today's media message.

Emma, a senior, wrote, "God is showing me that I am worth so much to Him, that I am his daughter and He loves me more than I could even imagine...He can take this broken mess and use it for His good."

Three of the students focused on spiritual growth. Lisa, a senior in the class wrote:

Through the talks that I had with my teacher and the encouragement from the passages she suggested I felt like I was really able to see what God was telling me to do. The guidance that she gave me, was not just a general saying any other teacher would say, it was heartfelt, God-inspired, and clearly stated.

The girls' journals had positive feedback concerning an all girls class taught by a female. According to the journal entries, the girls felt safe to confide personal information in the class. In this secure environment, they were able to learn and grow in their faith.

\section{Improvements}

The last journal prompt asked the girls what they would do to improve the class. In this section, the girls included what they did not like in the class, and they gave suggestions for improvements to the class. The two areas they did not like had to do with 
BIBLE DEPARTMENT GENDER ISSUES

classroom curriculum: notes and a book they read. Jill, a junior, focused on the size of the class:

I feel like maybe there were a few too many girls in here. I feel like maybe with fewer people, you could get deeper and grow closer together. I know that I might have shared more if there were fewer people.

Another junior, Mary, stated the class was awkward at times because of the nature of some of the conversations; however, it was better to have these conversations in an environment of all girls.

The areas for improvement were helpful; however, the overall entries were very insightful. The entries speak specifically to the benefits of the all girls Bible class taught by a female. 


\section{BIBLE DEPARTMENT GENDER ISSUES}

\section{Chapter 5: Summary}

This action research study, conducted in a mixed method based on a dominant status concurrent, QUAN + qual design, was driven by three research questions that examined the staff make-up of Bible departments in Christian high schools in Ohio. The purpose of this study was to assess administrators, parents, and students' perceptions of female, Bible teachers. Through surveys and journals, the study explored the following three research questions:

1. What is the staff make-up of Bible departments in Christian high schools in Ohio?

2. How do Ohio Christian school administrators, parents, and students view the position of females teaching Bible to high-school females?

3. If a Bible department at a Christian school in Ohio does not have a female staff member, do the female students have a female staff member they feel they can safely confide in with their personal, private concerns?

\section{Interpretation of the Results}

The administrators' survey addressed the first research question, the staff makeup of Bible departments. The male to female student ratio at the Christian schools surveyed was practically $50 \%$ to $50 \%$. However, there were 75 male teachers $(72.8 \%)$ and 29 female teachers (28.2\%). With only $28 \%$ of the Bible departments staffed with females and the male to female student ratio about $50 \%$, the proportion of female teachers was significantly less than the proportion of female students. Based on this, a female teacher in this study would be responsible for teaching 100 students, while a male 


\section{BIBLE DEPARTMENT GENDER ISSUES}

teacher would have 20 students. There are significantly fewer female Bible teachers than male teachers in Ohio's Christian high schools.

Kyle, an administrator of a large Christian school in Southern Ohio commented on the study after he took the survey. He said that, for him, the issue was not that he did not want to hire female Bible teachers; the issue was that female teachers do not apply for the Bible positions. In the last ten years, for every 30 male applicants he receives for a Bible position, he has one female applicant. This could provide one explanation for the lower numbers of female staff members in Bible departments.

The perceptions of administrators, parents, and students found in the survey and through the journal responses answered the next research question regarding women teaching the Bible to female students. Initially, the survey asked administrators if women could teach the Bible. Table 1 shows that four male administrators agree women should not teach the Bible, and no female administrators agree. These men (10.8\%) may have affected the test of concordance statistically significant. This could tentatively suggest that male administrators are more likely than female administrators to agree that females should not teach the Bible.

Next, the survey asked administrators if females can teach the Bible to female students. The relationship between respondent gender and attitude regarding whether women should teach Bible to girls is not statistically significant. While this may not be significantly significant, only 4 of 36 administrators (11.1\%), two females and two males, disagree with this statement, which may suggest most administrators do not disagree with females teaching the Bible to female students. 


\section{BIBLE DEPARTMENT GENDER ISSUES}

The survey then asked administrators if females can teach the Bible to male students. Five of 35 administrators (14.3\%) disagree with this statement. When this question was analyzed by school size, a significant relationship was shown between the response and school size. This may be due to the fact no administrator in schools with enrollments greater than or equal to 150 students disagree or strongly disagree with this statement. The five administrators who disagree or strongly disagree with the statement have schools with 150 or less students. Larger schools having 150 or more students may have affected the mean.

Based on the administrators' responses, some school administrators may object to females teaching the Bible in general to male or female students. However, overall, administrators do not object to female teachers teaching the Bible to female students.

The survey asked parents their perceptions of females teaching the Bible. While there was not a relationship between the genders of the parents and their answers, the study does show that $77.3 \%$ of the parents do prefer a female teacher for their daughters. This implies that parents want their female students taught by a female Bible teacher.

The student survey looked at the third research question. It appears students feel comfortable confiding in both male and female teachers. Of both male and female students surveyed, 14 of 19 students (82.4\%) feel comfortable confiding in a male teacher. However, only $62.5 \%$ of the female students feel comfortable in confiding in a male teacher, whereas $87.5 \%$ of the female students feel comfortable confiding in a female teacher. These results may suggest a gender preference. This supports the third research question. Students do confide in other staff members of the same sex. 


\section{BIBLE DEPARTMENT GENDER ISSUES}

Specifically, female students who do not have a female Bible teacher will confide in other female staff members.

The qualitative portion of the study further supports the second research question. In this study of an all girls Bible class, the female students prefer a female Bible teacher. Twelve of the 14 girls (85.7\%) wrote they prefer an all girls Bible class, taught by a female teacher.

A few of the girls claimed their female teacher provides a safe environment for them to be open, real, and honest with themselves and with each other. The girls prefer the class be taught by a female because they can discuss issues specifically pertinent to females. Based on the girls' journal comments, the girls listed 31 issues with which they struggle. Mentoring and shaping occurred in the all girls environment because they could safely discuss the issues with a female teacher.

The girls' journals allude to spiritual growth. Uecker (2008) found that while Christian schools were dedicated to teaching both religion and academics, their primary focus was biblical instruction through Bible classes. Based on the girls' journals, biblical instruction did occur in the class because girls were individually able to confront the lies the world was telling them with Bible truths.

The perceptions found in the girls' journals supports the idea that female students do not object to a female Bible teacher.

In the schools surveyed, only $28.2 \%$ of the teachers make up the female staff members in the Bible departments. Based on the administrators' comments, more males tended to be opposed to females teaching Bible; however, overall, administrators are not opposed to female Bible teachers. More administrators either agreed or strongly agreed 


\section{BIBLE DEPARTMENT GENDER ISSUES}

with the statements that females can teach Bible. With $77.3 \%$ of the parents in the study preferring an all girls Bible class for their female student, $85.7 \%$ female students in the study wanting an all girls Bible class, and $82.4 \%$ of all students confiding in an adult of the same sex, there is some credence to this study.

\section{Biblical Integration}

Christian educators, especially those in a Christian school, must analyze the issue of females teaching and mentoring younger girls from a Christian perspective. In Titus 2:3-5, Paul instructed Titus to teach the older women to live reverent lives and to adhere to sound doctrine so they, in turn, can teach what is good and appropriate to the younger women. Women who have been under the teaching of sound doctrine from men are to teach and mentor younger women. The book of Ruth is a picture of an older woman, Naomi, who had a close relationship with Ruth, a younger woman whom she taught and mentored. Naomi taught Ruth, a Moabite, of her God, the customs of her people, and the proper behavior of a young female. This was specifically illustrated in her advice to Ruth concerning her behavior towards Boaz. Another example of a mentor relationship found in the Bible is Timothy's mother Eunice and his grandmother Lois (II Timothy 1:5). Lois' faith was passed down to Eunice, who then taught it to Timothy. The Proverbs 31 woman is yet another example of a teacher and mentor to younger women, for "She riseth also while it is yet night, and giveth meat to her household, and a portion to her maidens" (Proverbs 31:15, King James Version). Hebrews 5:13-14 states that milk is for the babe in Christ; however, meat is reserved for those who have the ability to discern good and evil. The Proverbs 31 woman provides meat, or instruction through mentoring, to the younger women with whom she has built a relationship (Trotter, 2008). 


\section{BIBLE DEPARTMENT GENDER ISSUES}

In Christian education, mentoring includes teaching sound doctrine to enhance the biblical educational process. As a Christian, the sound doctrine I have received throughout the years should be shared with those I disciple or instruct (Trotter, 2008). I must wisely use sound doctrine in teaching my female students; as Paul instructs, "Do your best to present yourself to God as one approved, a workman who does not need to be ashamed and who correctly handles the word of truth" (II Timothy 2:15, New International Version).

\section{Relation of the Results to Literature}

Previous research studies show mentoring is an effective tool in adolescents' lives. In the current study, the female students enrolled in an all girls Bible class shared that they feel comfortable learning from and sharing with other girls in the safe environment of an all girls class, taught by a female. They mentioned connecting.with and trusting the other girls in the class. Similarly, Parks (1991) stated that mentoring in a group setting creates a sense of belonging (p. 89). In the Christian school setting, as students observe a teacher who models Christ to them, they themselves begin to develop morally (Algera \& Sink, 2002).

In the current study, the results from the parent survey showed that $77.3 \%$ of the parents prefer an all girls class taught be a female for their girls. When surveyed, $62.5 \%$ of the girls said they felt comfortable confiding in a male teacher; however, when asked if they felt comfortable confiding in a female teacher, $87.5 \%$ of the girls said they did. In 12 of the 14 journal entries $(85.7 \%)$, the female students revealed a preference for an all

girls class taught by a female. Previous studies show, students prefer talking to teachers 
BIBLE DEPARTMENT GENDER ISSUES

of the same sex when sharing personal issues (Francis et al., 2008; Spencer \& Liang, 2009).

Journal entries revealed the female students struggled with personal issues, such as dating, boundaries in relationships, rape, pornography, sex, sexually transmitted diseases, pregnancy, and self-image. Previous studies address the above behaviors as current issues that students face (Adrian et al., 2010; Bruce \& Cockreham, 2004; Leonard \& Scott-Jones, 2010; Milot \& Ludden, 2009).

The relationship built between the female teacher and students in the current study allowed the girls to focus on and discuss the following issues with which they struggle: sex, self-image, pornography, dating and boundaries in relationships, rape, sexually transmitted diseases, and pregnancy. A few of the girls wrote that, by the end of the class, their negative self-images had changed because they realized they were treasured daughters of God. This relationship is similar to Mills' (2003) description of modeling, in which the teacher helps the students confront and evaluate society's issues using a biblical perspective.

\section{Strengths of the Study}

This project involved action research that resulted in findings that may be applicable to some of the schools who participated in the study and possibly to other Christian schools, specifically those in Ohio and perhaps to other Christian schools in the United States. Unlike previous studies, this research focused on gender issues within Christian high school Bible departments in Ohio. The study researched the perceptions of administrators, parents, and students of Ohio's Christian schools through surveys and journals. Administrators surveyed said that, overall, their schools had 74 male Bible 


\section{BIBLE DEPARTMENT GENDER ISSUES}

teachers (71.8\%) and 29 female teachers (28.2\%). Obviously, more males than females are teaching in these Bible departments; however, this is not surprising when one looks at other results found in the study. Based on the study, overall, administrators are not opposed to female staff members teaching Bible to female students; however, more administrators, specifically male administrators, were opposed to female staff members teaching male students the Bible. On the other hand, the results of the administrators' survey showed that, of the 37 schools surveyed, 19 schools (51.4\%) already have female staff members teaching in their Bible departments.

Previous gender matching studies observed student perceptions of teachers; however, this study evaluated the perceptions of parents. The study revealed that parents look favorably upon female Bible teachers teaching their female students. Christian school administrators who participated in this study and others who did not participate could take this information and ask the parents of their schools if having a female Bible teacher is something they would want for their daughters.

If other female staff members outside of the Bible department are not available for students to confide in, potential areas for improvement could be revealed to school administrators who participated in the study and perhaps to other Christian school administrators who did not participate in the study. This study did reveal that six of the eight female students (75.0\%) surveyed had a female staff member with whom they could confide. Based on the results of the study, with administrators, parents, and students not overly opposed to female Bible teachers, administrators of Christian schools could evaluate the make-up of their Bible department staff to see if it would be advantageous to add a female Bible teacher. 


\section{BIBLE DEPARTMENT GENDER ISSUES}

Through three prompts, the students in an all girls Bible class wrote about their perceptions of the class. The girls were asked what they liked about the class, what they did not like about the class, and how they would improve the class. Nancy, a senior in the all girls Bible class wrote, "[This is] one of the best Bible classes I have ever taken. Every girl should take it." Jill, a junior, wrote, "I love this class! It is just a fun easy class full of challenges and unlike other classes; it is very practical and deals with what is happening today in the world." While previous studies have not researched an all girls Bible class, this study showed that a group of adolescent girls were receptive to the idea and liked taking an all girls Bible class. Based on previous studies, it is apparent that adolescents face many issues in today's world. This study analyzed an all girls Bible class and found the issues that adolescent girls face could be safely discussed in this environment. The reported results from the journals are most applicable to an all girls Bible classroom setting. These results could also be applicable for Christian schools that are considering offering an all girls Bible class, or the administrators could evaluate their

student body populations to see if an all girls Bible class would be advantageous for their female students.

\section{Limitations of the Study}

\section{Remaining Threats to Internal Validity}

Surveys were sent specifically to administrators of Christian schools in Ohio. In order to have a decent sample size, random selection did not occur because every administrator who had an email address received the survey. Random selection did not occur in the next round of surveys, parent surveys, because the administrators of the Christian schools sent the survey link to parents and guardians of the students in their 


\section{BIBLE DEPARTMENT GENDER ISSUES}

Christian school. The parents then sent the student survey to their students, which canceled out random selection.

Since this study was conducted only in Christian schools in Ohio, it resulted in a relatively small data set. At one of the schools where the administrator initially received a survey and did not respond, the enrollment was so small that they did not have a Bible department. Two administrators who received the survey did not respond because, while they were listed as a school, in reality, they were homeschool satellite bases.

Additionally, in the administrators' survey, two male administrators did not answer all of the questions. This may have had a slight effect on the results of that portion of the study.

Only one administrator sent the parent survey link to the parents of the students at their school. This created an even smaller data set for both parents and students. Luke, an administrator in Central Ohio, told me it was his school's policy not to forward nonschool generated surveys to employees, parents, or students. This administrator also said most schools would take this position on surveys.

Wording in the administrators' survey changed between questions 10-12. Question 10 said, "Female staff members should not teach the Bible." Questions 11-12 said, "Female staff members can teach." This change may have affected some of the responses because the administrators may have continued answering "should not" rather than carefully reading the next two statements.

The qualitative portion of the study also resulted in a relatively small data set. The school only had one all girls Bible class. Comparative analysis of the journal 


\section{BIBLE DEPARTMENT GENDER ISSUES}

transcripts showed consistent and repeated results. While saturation was apparent in the students' journals, it was still a small data set.

\section{Remaining Threats to External Validity}

In order to have a decent sample size in the quantitative portion of this study, random selection could not occur because the administrators surveyed were solely administrators of Christian schools. More specifically, they were administrators of Christian schools in Ohio. The diversity of the students from the qualitative portion of this study was also limited. Thirteen of the 14 girls (92.9\%) were Caucasian. All of the girls lived in Central Ohio. As a result, the study was highly focused on a select group of people and schools; therefore, the results may not be as applicable to other schools in the United States. While information may not be generalized across other schools, beneficial educational information can be gained from this study and may be applied to other educational settings that share similar characteristics.

There was potential for demand characteristics to have occurred in the qualitative portion of the study. The 17 girls in the all girls class were people pleasers and naturally do not want to offend anyone. In order to try to avoid this, the questions were written on the chalkboard, and the instructor told the girls to answer the questions honestly in their journals. The three prompts were written on the board to try to prevent the personal bias of the instructor from influencing the girls' responses. The instructor then went to the back of the classroom and quietly sat down trying to be inconspicuous, so as not to sway the girls' responses. At the end of the period, the instructor then collected the journals. 


\section{BIBLE DEPARTMENT GENDER ISSUES}

\section{Suggestions for Future Research}

This study should be expanded to include a greater number of Christian high schools across a larger geographic region. It should include a greater number and diversity of people.

The study focused on high school Bible departments. Future studies could extend to middle schools to evaluate the perceptions of administrators, parents, and students to see if there is a need for gender matching within middle school Bible departments.

As far as gender issues, the study focused on the perceptions of female teachers teaching Bible. Future studies should expand this to female teachers' perceptions of gender harassment in high school Bible teaching positions. Another study could expand to students' perceptions of male teachers.

One of the surveys in the study asked administrators their perceptions of whether female Bible teachers should or should not teach the Bible to male or female students. Future study should expand this to a qualitative study that asks administrators to state their beliefs as to why females should or should not teach the Bible to students, specifically to male students or female students.

The qualitative portion of this study focused on student perceptions of an all girls Bible class. Future study should expand this to more all girls Bible classes or to all boys Bible classes.

The students in the all girls class spoke about how their lives had been challenged. A longitudinal study could focus on following the lives of girls who have been members of an all girls Bible class to observe their lives in relation to the values that were taught in the class. 


\section{BIBLE DEPARTMENT GENDER ISSUES}

Journals from the all girls Bible class contained information about the various issues some girls experience. Future research could analyze if curriculums in Bible classes are addressing the issues students face. Another study could see if Bible textbooks are the best method of teaching relevant student issues.

This study also looked at other female staff members with whom female students confide. Future studies could focus on the mentoring styles and opportunities of these individuals within the school environment. 


\section{BIBLE DEPARTMENT GENDER ISSUES}

\section{References}

Adrian, M., Zeman, J., Erdley, C., Lisa, L., \& Sim, L. (2010). Emotional dysregulation and interpersonal difficulties as risk factors for nonsuicidal self-injury in adolescent girls. Journal of Abnormal Child Psychology, 39(3), 389-400. doi: $10.1007 / \mathrm{s} 10802-010-9465-3$

Algera, H. F., \& Sink, C. A. (2002). Another look at character education in Christian schools. Journal of Research on Christian Education, 11(2), 161-181. doi: $10.1080 / 10656210209484937$

Archibald, G. (2004, June 30). Millions of students see sex misconduct. The Washington Times. Retrieved from http://www.washingtontimes.com/

Aultman, L. P., Williams-Johnson, M. R., \& Schutz, P. A. (2009). Boundary dilemmas in teacher-student relationships: Struggling with "the line." Teaching and Teacher Education, 25(5), 636-646. doi: 10.1016/j.tate.2008.10.002

Barrett, D. E., Headley, K. N., Stovall, B., \& Witte, J. C. (2006). Teachers' perceptions of the frequency and seriousness of violations of ethical standards. Journal of Psychology, 140(5), doi: 421-433. 10.3200/JRLP.140.5.421-433

Boerema, A. J. (2011). A research agenda for Christian schools. Journal of Research on Christian Education, 20(1), 28-45. doi: 10.1080/10656219.2011.557564

Boldero, J., \& Fallon, B. (1995). Adolescent help-seeking: What do they get help for and from whom? Journal of Adolescence, 18(2), 193-209. doi: 10.1006/jado .1995 .1013

Bruce, M. A., Cockreham, D. (2004). Enhancing the spiritual development of 


\section{BIBLE DEPARTMENT GENDER ISSUES}

adolescent girls. Professional School Counseling, 7(5), 334-342. Retrieved from http://www.schoolcounselor.org/content.asp? contentid=235

Burnett, C., Jr. (2011, December 13). Teacher set for trial on sex charge. Lancaster Eagle Gazette. Retrieved from http:/www.lancastereaglegazette.com/

Cannister, M. W. (1999). Mentoring and the spiritual well-being of late adolescents. Adolescence, 34(136), 769-779. Retrieved from http://www.highbeam.com /publications/adolescence-p4790

Carrington, B., \& Skelton, C. (2003). Re-thinking 'role-models': Equal opportunities in teacher recruitment in England and Wales. Journal of Education Policy, 18(3), 253-265. doi: 10.1080/02680930305573

Carrington, B., Tymms, P., \& Merrell, C. (2008). Role models, school improvement and the 'gender gap' - do men bring out the best in boys and women the best in girls? British Educational Research Journal, 34(3), 315-327. doi: 10.1080 /01411920701532202

Dawidowicz, P. M. (2003). Teaching morality in schools in Utah's religion-based society. Journal of Moral Education, 32(2), 275-289. doi: 10.1080 10305724032000136707

Driessen, G. (2007). The feminization of primary education: Effects of teachers' sex on pupil achievement, attitudes and behavior. International Review of Education, 53(2), 183-203. doi: 10.1007/s11159-007-9039-y

Francis, B., Skelton, C., Carrington, B., Hutchings, M., Read, B., \& Hall, I. (2008). A 


\section{BIBLE DEPARTMENT GENDER ISSUES}

perfect match? Pupils' and teachers' views of the impact of matching educators and learners by gender. Research Papers in Education, 23(1), 21-36. doi:

$10.1080 / 02671520701692510$

Georgiou, S. N., Demetriou, A. P., \& Stavrinides, P. (2008). Attachment style and mentoring relationships in adolescence. Educational Psychology, 28(6), 603-614. doi: 10.1080/01443410801982517

Green, J. (2006). Christ-centered, diverse, and academically excellent: The origins of a possible model for Christian schooling in the twenty-first century. American Educational History Journal, 33(1), 89-95. Retrieved from http:/www.infoagepub .com/american-educational-history-journal.html

Jeynes, W. H. (2009). The relationship between biblical literacy, academic achievement, and school behavior among Christian- and public-school students. Journal of Research on Christian Education, 18(1), 36-55. doi:

$10.1080 / 10656210902751826$

Johnson, B., \& Christensen, L. (2004). Educational research: quantitative, qualitative, and mixed approaches (2nd ed.). Boston, MA: Pearson.

Johnson, L. K. (2011). Keeping women silent: A study of female leadership in faith based institutions. Available from ProQuest Dissertations and Theses database. (UMI No. 3465391)

Jones, S. C., \& Rossiter, J. R. (2009). Social and religious factors in adolescents' drug use. Journal of Child \& Adolescent Substance Abuse, 18(1), 85-92. doi: 10.1080 $/ 15470650802544180$

Leonard, K., \& Scott-Jones, D. (2010). A belief-behavior gap? Exploring religiosity 


\section{BIBLE DEPARTMENT GENDER ISSUES}

and sexual activity among high school seniors. Journal of Adolescent

Research, 25(4), 578-600. doi: 10.1177/0743558409357732

Lewis Hall, M. E., Christerson, B., \& Cunningham, S. (2010). Sanctified sexism:

Religious beliefs and the gender harassment of academic women. Psychology of Women Quarterly, 34(2), 181-185. doi: 10.1111/j.1471-6402.2010.01560.x

Ludlow, R. (2011, October 28). Grand jury indicts teacher for sex with 15-year-old girl. The Columbus Dispatch. Retrieved from http://www.dispatch.com/

MacArthur, J. (1996). The MacArthur New Testament commentary: Titus. Chicago, IL: Moody.

Maimon, D., \& Kuhl, D. C. (2008). Social control and youth suicidality: Situating Durkheim's ideas in a multilevel framework. American Sociological Review, 73(6), 921-943. doi: 10.1177/000312240807300603

Mills, K. A. (2003). The culture of the Christian school. Journal of Education and Christian Belief, 7(2), 129-142. Retrieved from http://www.jecb.org/

Milot, A. S., \& Ludden, A. B. (2009). The effects of religion and gender on wellbeing, substance use, and academic engagement among rural adolescents. Youth and Society, 40(3), 403-425. doi: 10.1177/0044118X08316668

Minitab 16 Statistical Software (2010). [Computer Software]. State College, PA: Minitab, Inc. Retrieved from http://www.minitabl.com

National Center for Education Statistics. (2011). Characteristics of private schools in the United States: Results from the 2009-10 Private School Universe Survey. In Private school survey. Retrieved from http://nces.ed.gov/pubsearch /getpubcats.asp?sid=002\# 


\section{BIBLE DEPARTMENT GENDER ISSUES}

Oldenburg, C. M. (2005). Students' perceptions of ethical dilemmas involving professors: Examining the impact of the professor's gender. College Student Journal, 39(1), 129-140. Retrieved from http://www.projectinnovation.biz /csj_2006.html

Parks, S. (1991). The critical years: Young adults and the search for meaning, faith, and commitment. New York, NY: HarperCollins.

Passe, J., \& Willox, L. (2009). Teaching religion in America's public schools: A necessary disruption. The Social Studies, 100(3), 102-106. doi: 10.3200/TSSS $.100 .3 .102-106$

Peace, M. (1997). Becoming a Titus 2 woman. Bemidiji, MN: Focus.

Richter, E. (2011, February 8). Female gym teacher accused of sex acts with football players. Dayton Daily News. Retrieved from http:/www.daytondailynews.com/

Sangiacomo, M. (2011, February 6). Teacher sentenced to 2 years for relationship with student. The Columbus Dispatch. Retrieved from http://www.dispatch.com/

Smith, C. (2003). Theorizing religious effects among American adolescents. Journal for the Scientific Study of Religion, 42(1), 17-30. doi: 10.1111/1468-5906.t01-1 $-00158$

Spencer, R., \& Liang, B. (2009). "She gives me a break from the world": Formal youth mentoring relationships between adolescent girls and adult women. The Journal of Primary Prevention, 30(2), 109-130. doi: 10.1007/s10935-009-0172-1

Trotter, M. (2008, September). The Virtuous Woman. Sermon presented at Northwest Bible Church, Hilliard, OH. 


\section{BIBLE DEPARTMENT GENDER ISSUES}

Uecker, J. E. (2008). Alternative schooling strategies and the religious lives of American adolescents. Journal for the Scientific Study of Religion, 47(4), 563584. doi: $10.1111 / \mathrm{j} .1468-5906.2008 .00427 . \mathrm{x}$

Van der Walt, J. L., \& Zecha, G. (2004). Philosophical-pedagogical criteria for assessing the effectiveness of a Christian school. Journal of Research on Christian Education, 13(2), 167-198. doi: 10.1080/10656210409484968

Watson, K. (2010). Contrasting policies towards (mainly) Christian education in different contexts. Comparative Education, 46(3), 307-323. doi: 10.1080 $/ 03050068.2010 .503743$

Wright, E. (1999). Religion in American education: A historical view. Phi Delta Kappan, 81(1), 17-20. Retrieved from http://www.kappanmagazine.org/ 


\section{BIBLE DEPARTMENT GENDER ISSUES}

\section{APPENDIX A SURVEY ADMINISTRATROR CONSENT FORM}

September 30, 2011

Dear Administrator,

Currently, I am working towards my Masters in Education at Cedarville University. The final requirement for the program is to complete a thesis. I am researching the staff make-up of Bible departments in Ohio Christian high schools. You have been asked to participate in this study because you are the administrator of a Christian school in Ohio.

To accomplish this, I am asking you to complete a short survey about your school's Bible department. You can find the survey at the following link: https://www.surveymonkey .com/s/59TXG52

I'm also going to ask you to send the following link to parents in your high school: https://www.surveymonkey.com/s/5RXMZ5Z. My reason for doing this is I want to know what parents views about a female teacher teaching a Bible class for high school girls.

The survey for parents will also include a link to a survey for their student to take. If they chose to let their student take it, the student will be asked if there is a staff member who they can talk to about any problems or issues they are experiencing.

There are no risks with this study. All of the information from the surveys will be kept confidential and names will be changed in any reports. Once calculated, the surveys will be destroyed.

Please complete the on-line survey by Friday, October 28. Thank you in advance for participating in the study. If you agree to participate in this study, remember that you may withdraw at any time, if you so decide. You may also refuse to answer any questions you do not want to answer.

Feel free to email me at elizabethhacker@gmail.com if you have any questions about this study.

Sincerely,

Elizabeth Hacker

The Cedarville University Review Board has reviewed my request to conduct this project. If you have any concerns about your rights in this study, contact Dr. Steve Gruber at grubers@cedarville.edu. 
BIBLE DEPARTMENT GENDER ISSUES

APPENDIX B

ADMINISTRATOR SURVEY

1. Please select your gender.

Male

Female

2. What is your age?
30-39
40-49
50-59
60-69
$70+$

3. What is the name of your school?

4. How many students are enrolled in your high school?

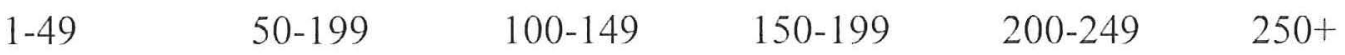

5. How many male students are in your high school?

6. How many female students are in your high school?

7. How many males teach in your Bible department?

8. How many females teach in your Bible department?

9. If you do not have a female Bible teacher, please state the title of the individual with whom your girls address their problems and issues.

Strongly Disagree Disagree Agree Strongly Agree

10. Female staff members should not teach the Bible.

11. Female staff members can teach female students the Bible.

12. Female staff members can teach male students the Bible. 


\title{
BIBLE DEPARTMENT GENDER ISSUES
}

\author{
APPENDIX C \\ SURVEY PARENTAL CONSENT FORM
}

September 30, 2011

Dear Parent/Guardian,

Currently, I am working towards my Masters in Education at Cedarville University. The final requirement for the program is to complete a thesis. I am researching the staff make-up of Bible departments in Ohio Christian high schools. You have been asked to participate in this study because you are a parent of a student enrolled in a Christian high school in Ohio.

To accomplish this, I am asking you to click on the following link and complete a short survey: https://www.surveymonkey.com/s/5RXMZ5Z.

I'm also going to ask that you consent to allow your student enrolled in high school take this survey. By sending the following link to your child, you are giving them consent to take the survey. Their survey can be found at the following:

https://www.surveymonkey.com/s /5RWCJW5. My reason for doing this is I want to evaluate parent and student views about the make-up of their school's Bible department.

There are no risks with this study. All of the information from the surveys will be kept confidential and names will be changed in any reports. Once calculated, the surveys will be destroyed.

Please complete the on-line survey by Friday, October 28. Thank you in advance for participating in the study. If you agree to participate in this study, remember that you may withdraw at any time, if you so decide. You may also refuse to answer any questions you do not want to answer.

Feel free to email me at elizabethhacker@gmail.com if you have any questions about this study.

Sincerely,

Elizabeth Hacker

The Cedarville University Review Board has reviewed my request to conduct this project. If you have any concerns about your rights in this study, contact Dr. Steve Gruber at grubers@cedarville.edu. 


\section{BIBLE DEPARTMENT GENDER ISSUES}

\section{APPENDIX D}

PARENT SURVEY

1. Please select your gender.

Male

Female

2. What is your age?

30-39

40-49

$50-59$

60-69

$70+$

3. What is the name of the school your student attends?

4. Select your student's grade (If you have more than one student in high school, select your daughter's grade or oldest student's grade).

9

10

11

12

5. In an ideal world, whom would you prefer your female student to discuss their problems and issues?

Male Bible teacher

Female Bible teacher

6. If you have a daughter, would you be interested in having her take an all girls Bible class that deal with her relationship with Christ and her relationship with her peers?
Yes
No
Does not apply 
BIBLE DEPARTMENT GENDER ISSUES

\author{
APPENDIX E \\ SURVEY STUDENT CONSENT FORM
}

September 30, 2011

Dear Student

Currently, I am working towards my Masters in Education at Cedarville University. The final requirement for the program is to complete a thesis. I am researching the staff make-up of Bible departments in Ohio Christian high schools. You have been asked to participate in this study because you are a student enrolled in a Christian high school in Ohio.

To accomplish this, I am asking you to click on the following link and complete a short survey: https://www.surveymonkey.com/s/5RWCJW5. My reason for doing this is I want to evaluate your view about the make-up of your school's Bible department.

There are no risks with this study. All of the information from the surveys will be kept confidential and names will be changed in any reports. Once calculated, the surveys will be destroyed.

Please complete the on-line survey by Friday, October 28. Thank you in advance for participating in the study. If you agree to participate in this study, remember that you may withdraw at any time, if you so decide. You may also refuse to answer any questions you do not want to answer.

Feel free to email me at elizabethhacker@gmail.com if you have any questions about this study.

Sincerely,

Elizabeth Hacker

The Cedarville University Review Board has reviewed my request to conduct this project. If you have any concerns about your rights in this study, contact Dr. Steve Gruber atgrubers@cedarville.edu. 


\section{BIBLE DEPARTMENT GENDER ISSUES}

APPENDIX F

STUDENT SURVEY

1. Please select your gender:

Male

Female

2. What grade are you in?

9

10

11

12

3. What is the name of your high school?

4. If you had a personal and private concern, would you feel comfortable confiding in male teacher?

Yes

No

5. If you had a personal and private concern, would you feel comfortable confiding in a female teacher?

Yes

No

6. Please select the gender of your current Bible teacher.

Male

Female

7. What is the position of the staff member at your school with whom you feel you can safely confide?

Principal Teacher Counselor Administrative Assistant Other (Please Specify)

8. Is this person the same sex as you?

Yes

No 


\section{BIBLE DEPARTMENT GENDER ISSUES}

\section{APPENDIX G \\ JOURNAL PARENTAL CONSENT FORM}

December 10,2011

Dear Parents/Guardians,

As I near the completion of Masters in Education at Cedarville University, I am writing my thesis. I am researching the Bible departments in Ohio's Christian schools. I would like your student's opinion of an all girls Bible class.

I had your students write a response to the class just because I want to improve God Meets Girl. After reading their papers, I was amazed how much their comments lined up with my thesis topic.

With your permission, I would like to use some of their responses in the thesis. All information from the written response will be kept confidential and names will be changed in any reports. Please sign and return the permission slip below by December 21. I appreciate your assistance. Feel free to email me if you have any questions.

Sincerely,

Miss Hacker

I give permission for my student's comments to be copied and transcribed. I understand that confidentiality will be maintained.

Student's name:

Date:

Student's signature:

Parent's signature: 


\title{
BIBLE DEPARTMENT GENDER ISSUES
}

\author{
APPENDIX H \\ REMINDER NOTE TO ADMINISTRATORS
}

October 14, 2011

Dear Administrator,

Previously I sent you an email asking you to take a short survey about your Christian school. I am working towards my Masters in Education at Cedarville University. The final requirement for the program is to complete a thesis. I would greatly appreciate your response to the survey. It would be helpful to me.

The survey will be open till October 28. You can find the survey at the following link: https://www.surveymonkey.com/s.aspx.

I'm also going to ask you to send the following link to parents in your high school: https://www.surveymonkey.com/s/5RXMZ5Z. My reason for doing this is I want to know what parents views about a female teacher teaching a Bible class for high school girls.

The survey for parents will also include a link to a survey for their student to take. If they chose to let their student take it, the student will be asked if there is a staff member who they can talk to about any problems or issues they are experiencing.

There are no risks with this study. All of the information from the surveys will be kept confidential and names will be changed in any reports. Once calculated, the surveys will be destroyed.

Thank you in advance for participating in the study. If you agree to participate in this study, remember that you may withdraw at any time, if you so decide. You may also refuse to answer any questions you do not want to answer.

Feel free to email me at elizabethhacker@gmail.com if you have any questions about this study.

Sincerely,

Elizabeth Hacker

The Cedarville University Review Board has reviewed my request to conduct this project. If you have any concerns about your rights in this study, contact Dr. Steve Gruber atgrubers@cedarville.edu. 
